\title{
Justification for Continued Operation of the SRS Saltstone Facility (Z-Area)
}

by

W. A. Wagner

Westinghouse Savannah River Company

Savannah River Site

Aiken, South Carolina 29808

DOE Contract No. DE-AC09-89SR18035

This paper was prepared in connection with work done under the above contract number with the U. S.

Department of Energy. By acceptance of this paper, the publisher and/or recipient acknowledges the U. S. Government's right to retain a nonexclusive, royalty-free license in and to any copyright covering this paper, along with the right to reproduce and to authorize others to reproduce all or part of the copyrighted paper. 


\section{DISCLAIMER}

This report was prepared as an account of work sponsored by an agency of the United States Government. Neither the United States Government nor any agency thereof, nor any of their employees, makes any warranty, express or implied, or assumes any legal liability or responsibility for the accuracy, completeness, or usefulness of any information, apparatus, product, or process disclosed, or represents that its use would not infringe privately owned rights. Reference herein to any specific commercial product, process, or service by trade name, trademark, manufacturer, or otherwise does not necessarily constitute or imply its endorsement, recommendation, or favoring by the United States Government or any agency thereof. The views and opinions of authors expressed herein do not necessarily state or reflect those of the United States Government or any agency thereof.

This report has been reproduced directly from the best available copy.

Available to DOE and DOE contractors from the Office of Scientific and Technical Information, P.O. Box 62, Oak Ridge, TN 37831; prices available from (615) 576-8401.

Available to the public from the National Technical Information Service, U.S. Department of Commerce, 5285 Port Royal Road, Springfield, VA 22161. 


\section{DISCLAIMER}

Portions of this document may be illegible in electronic image products. Images are produced from the best available original document. 
April 9.1992

Mr. C. W. Terrell. Acting Director

Defense Waste Processing Division

Savannah River Field Office

L.S. Department of Energy

Aiken. SC 29802

Dear Mr. Terrell:

USTIEICATION FOR CONTINUED OPERATION UCOY OE THE. SRS SALTSTONE EACILITY(Z-AREA) (U)

Ref. 1. Memo from C. W. Terrell. Acting Director, High Level Waste Division, DOESR, to D. B. Amerine. Manager, WSRC (DWPF), dated March 20. 1992, Justification of Continuing Operations (JCO) of the Saltstone Facility.

2. Memo from C. W. Terrell, Acting Director, High Level Waste Division, DOESR. to D. B. Amerine, Manager, WSRC (DWPF), dated November 20, 1992. Z-Area Safety Analysis Report.

3. Letter from W. T. Goldston, DWPF WSRC, to H. Gnann, DOE-SR Saltstone SAR/6430.1A Compliance Review, dated August 30, 1991.

4. Memo from A. L. Watkins, DOE-SR to J. F. Ottaldo, dated March 20, 1990. Saltstone SAR Format.

As requested (ref 1), attached is the Justification for Continued Operation (JCO) for the Saltstone Facility (Z-Area). The JCO allows continued operations of the Saltstone Facility until a Safety Analysis Report is approved. As noted in the independent reviews during the Z-Area Operational Readiness Review and DOE-HQ Startup Authorization Reviews, all safety issues related to Z-Area were found to be adequately addressed in existing safety documentation for the Low Hazard Saltstone operations. The facility was authorized by DOE to begin radioactive operations in June 1990 with the requirement to revise the safety documentation to comply with the level of detail required by DOE Order 5481.1B. The Salestone Facility has operated since that time and demonstrated through an excellent safery record that the authorization decision was correct and well-founded. As docurnented in the $\mathrm{JCO}$, hazards and risks to onsite or offsite populations are not increased due to continued operations of Z-Area. 
C. W. Tertell

OPS-DTL-92-0039

Page 2

April 9.1992

As you know. we have drafted a Safety Analysis Report for Z-Area. the format and content of which conforms to a DOE directed graded approach to Low Hazard facilities (ref 4). When the work to complete the SAR was suspended (ref 2), the document was just beginning internal Westinghouse review and was on schedule to be completed and submitted to DOE for review by Docember 31, 1991. The resources to complete the intemal review, resolve comments and publish the draft for DOE review were assigned to other tasks. As a result, the costs and schedule provided in ref 3 are no longer valid.

The additional funding required to restaff the effort provide internal review and resolution of comments is approximately $\$ 250,000$. We can begin the effort as soon as funding is authorized and provide a draft for DOE review 6 months from authorization to proceed. We should note that this estimate does not include the additional cost to respond to the DOE review and approval cycle. nor does it include costs to complete the DOE 6430.1A design comparison (approximately $\$ 550,000$ and $\$ 650,000$. respectively).

We stand ready to complete the Saltstone SAR upon your authorization of funds. Any questions you or your staff may have may be directed to me. W. T. Goldston, or Dr. J. R. Fowler.

Sincerely.<smiles>CC(C)C1C2CCC1CC2</smiles>

D. B. Amerine, Manager

Defense Waste Processing Facility

WTG/sm

œ: $\quad$ N. C. Boyter, 703-A

R. M. Satterfield. 773-70A

D. B. Amerine, 704-S

J. F. Ortaldo, 704-S

W. T. Goldston, 704-S

J. R. Fowler. 704-Z

H. Bull, 704-Z

D. G. Thompson, 704-Z

E. L. Wilhite, 773-43A

R. R. Campbell, 703-A
D. W. Call, 992-2W

N. F. Sadri, 992-2W

K. W. Stevens, 992-1W

M. S. Williams, 992-1W

D. H. Howand, 992-1W

L. C. Sjostrom, 703-A

S. Ordway, 704-S

P. A. Polk, 704-S

Area Files, TC-S1

Central Files, 703-A 
WSRC-RP-92-444

March 31, 1992

\title{
WESTINGHOUSE SAVANNAH RIVER COMPANY WMEER DIVISION \\ DEFENSE WASTE PROCESSING FACILITY DWPF TECHNICAL \\ Regulatory Compliance AND \\ Saltstone Technology Group
}

\section{Justification for CONTINUEd Operation OF THE} SRS SALTSTONE FACILITIES (Z-AREA)

\author{
UNCLASSIFIED
}




\begin{tabular}{|c|c|c|c|}
\hline WEBTIHGHOOBE BAVAWHAR RIVER COKPAKY & & Report: & WSRC-RP-92-444 \\
\hline $\begin{array}{l}\text { Justification for continued operation } \\
\text { of the sRs saltstone pacilities (z-Area) }\end{array}$ & (U) & $\begin{array}{l}\text { page: } \\
\text { Date: }\end{array}$ & $\begin{array}{l}1 \text { of } 16 \\
3 / 31 / 92\end{array}$ \\
\hline
\end{tabular}

\subsection{INTRODUCTION AND SUMMARY}

\subsection{INTRODUCTION}

Saltstone Production and Disposal Facilities (Z-Area) are part of the Defense Waste Processing Facilities (DWPF). Z-Area facilities are actually just one segment of an integrated waste management and disposal system located at the Savannah River Site (SRS). This integrated system is designed to treat liquid High Level Waste (HLW) generated and stored at the Savannah River Site (SRS) and convert the liquid waste into solid waste forms suitable for final disposal. This system is designed to eliminate interile storage of liquid HLW in large underground tanks at the SRS. $z$ Area is a critical part of this integrated system because it treats and disposes of mixed IIquid waste and LLW generated in other waste treatment facilities that are a part of the integrated syster. Z-Area operations are an integral part of SRS meeting DOE's committments in the Federal Facility Compliance Agreement (FFCA). Z-Area facillties will be used to treat and safely dispose of more than 90 of the mixed wastewater that will be generated from HLW presently stored in waste tanks. Wastewater generated by the F/H Effluent Trestment Facility is also sent to Z-Area for treatment and final disposel. Existing waste inventory at the site wlll require treatment and disposal of about 17,000,000 gallons of mixed wastewater in 2-Area. Radioactive startup was authorized by the Department of Energy in June 1990. (Ref. 12, 13) Since startup, Z-Area operations have safely treatad and disposed of more than 1 million gallons of mixed wastewater as a non-hazardous, solid waste known as Saltstone.

If Z-Area operations are stopped, the In-Tank Precipitation Process (ITP) will not be allowed to start because storage for treated mixed wastewater from the ITP process is not avallable. ITP is designed to decontaminate the soluble fraction of $\mathrm{HLW}$ presently stored in the Tank Farms, and Z-Area disposal of the decontaminated wagtewater is required in order to run the ITP process. Eventually, the F/H Effluent Treatment Facility (ETF) at the SRS will also be forced to shut down due to lack of storage space for LIV wastewater generated in the ETF process. If ETF stops operation, waste evaporators in the Tank Farms and Separations Areas must also stop operating, because current regulations do not allow overheads from these ovaporators to be reloased to the environent without first treating the overhesds at the ETF. Extended Sludge Processing (ESP), an in-tank process that generates an HLW sludge feed stream to be sent to the Vitrification Facility of the DWPF, will not be able to operate because spent washwater from the ESP must be processed through the waste evaporators located in the Tank Farms. Radioactive startup of the S-Area Vitrification Process will thus be delayed because thl waste streams to be treated in S-Area are generated by ITP and ESP treatment.

The bases for the Justification of Continuing Operations (JCO) of the Saltstone Production and Disposal Facilities (Z-Area) at the Savannah River site (SRS) are provided. Continued Z-Area operations are jeopardized due to non-compliance with DOE Orders and the DOE Order compllance schedule for Z-Area. The compliance schedule shows that WSRC was to issue a Safety Analysis Report (SAR) by December 1991 that conforms to the format described in DOE Order 5481.1B. Funding was provided in FY9O and FY91 to enable WSRC to complete a Z-Area SAR. Because of budgetary constraints, funding for the Z-Area SAR was suspended at the beginning of FY92 by DOE, since the low-hazard nature of $\mathrm{z}$-Area operations does not pose a signiflcant safety risk to 
onsite or offsite populations. (Ref. 1) Available resources were redirected to startup efforts for the S-Area Vitrification Facility at the SRS (1780 Profect). Lack of funding by DOE has prevented WSRC from meeting the projected compliance schedule for the Z-Area SAR.

\subsection{SUMMARY}

An Operational Readiness Review (ORR) conducted in 1988 and the Startup Authorization Review conducted in 1990 demonstrated the readiness and safety of the new Z-Area facilities and proposed method of operations from the standpoints of: (1) plant and hardware; (2) administrative controls and procedures; and (3) personnel resdiness and training. In the ORR for Z-Area, DOE-HQ (EH) concurred with DOE-SR that all safety issues have been adequately addressed in existing safety docunentation and an effective safety envelope for Z-Area operations has been established. However, the documentacion does not match the format or level of detail prescribed in DOE Order S481.1B, and thus does not fully comply with the order. (Ref, 3, 4) In the startup Authorization Review, this non-compliance with DOE Order $5480.1 \mathrm{~B}$ is clearly identified as one of forw, not substance, because Z-Area operations are extremely Low Hazard (localized consequences only). (Ref. 5) No safety-class items have been identified for Z-Area operations.

Prior to halting work on the Z-Area SAR, a radiological hazards analysis of z-Area facilities and a WSRC Review Draft of a Z-Area SAR wero completed. (Ref. 7, 8, 9, 10) Results shown in these reports also support the earlier conclusions reached in the ORR and Startup Authorization Review: Saltstone production operations and the related Saltatone disposel in Z-Area are clearly Low Hazard and pose no significant rlaks to elther onsite or offsite populations.

Salt solution is the only hazardous material that could be present in a significant quantity in Z-Area. The maximum quantity of salt solution that could be present is $45,00 \%$ gallons, the capacity of the Salt Solution Hold Tank (SSHT) used to recelve and stiore the solution prior to treatment in the Saltstone Production Facility. Although a significant quantity of Saltstone (and radionuclides contalned by the Saltstoni) will eventually be present in 2-area disposal vaults, the solid Saltstone is a stable, nonhazardous waste form that contains low concentrations of radionuclides.

No credible event can be postulated that would result in a direct instantaneous release of a significant quantity of radionuclides from the stable Saltstone waste form. Based on regulatory testing, both Saltstone grout and solid Saltstone are legally considered to be nonhazardous waste by the South Carolina Department of Health and Environmental Control (SCDHEC), the state authority that regulates waste disposal in 2-Area vaults. Z-Area's disposal facflity is permitted by the SCDHEC as an Industrial Waste Landfill that is used only for the disposal of nonhazardous solid waste (Saltstone). Saltstone provides primary contalnment for radionuclides and chemicals in the waste, and the vaults provide secondary containment. Neither the Saltstone grout produced in 2-Area nor the solldifled saltstone contained in large concrete vaults pose any hazard to the public or to site employees. (Ref. 2, 7, 8, $9,10)$ The risk to site personnel and the public is greater if the salt solution is stored instead of converting the solution to a stable solid Saltstone suftable for disposal. 


\subsubsection{Hazards Analysis}

To be classified as a Low Hazard nuclear facility, the unmitigated effective dose equivalent (EDE) must be below 5 Rem at 100 meters and below 0.5 Rem at the site boundary. Using the feed specifications in the Test Authorization for waste transfers to Z-Ares as a basis, the EDE for the vaults and Salt Solution Hold Tank (SSHT) In Z-Area were calculated; results were well below the maximum values for a Low Hazard facility (Ref. 7,8 ):

$\begin{array}{lll} & \text { EDE at } & \text { EDE at } \\ 100 \text { Yeters } & \text { Site Boundary } \\ \text { Vaults } & 0.644 \text { Rem } & 0.001 \text { Rem } \\ \text { SSHT } & 1.03 \text { Rem } & 0.002 \text { Rem }\end{array}$

The Saltstone Production Facility meets the DOE definltion of a Nonreactor Nuclear Facility. The Saltstone disposal vaults do not meet the definition of a Nonreactor Nuclear Facility because the form of the waste is not considered hazardous, even though a significant quantity of $L L W$ waste will be present as disposal operations continue. Both form and quantity of nuclear materlals determine if a facility should be designated as a Nonreactor Nuclear Facllity.

\subsubsection{Safety Analysis}

Normal operations pose no undue radiological or chemical hazards to onsite and offsite populations. The EDE for onsite population due to Z-Area operations is 1.4E5 person-Rem. For the offsite population, the EDE for the maximally exposed offalte individual is $3.6 \mathrm{E}-6$ mRem. The EDE for the $50-\mathrm{mile}$ offiste population $1 \mathrm{a} 1.0 \mathrm{E}-4$ pefson-Rem. Chemical hazards due to hazardous contaminants are two to eleven orders of magnitude below the chronic occupational exposure limits as they enter the stack fox relesse. Subsequent air dilution effectively eliminates these specles as a hazard. The high pH of the wastewater poses a hazard during sampling and analyses, but adainistrative controls, industrial hyglene prectices, training and operating procedures are in place to preclude any unnecessary risk to operating personnel. (Ref. 2, 10)

A conservative worst unmitigated accident scenarlo was analyzed as a part of the WSRC Review Draft of the Z-Area SAR. This scenario was used to bound the consequences of any credible event that could occur in Z-Area due to the presence of the hazardous aalt solution. This bounding gcenario assumes: (1) the SSHT is filled to capacity; (2) concentrations of radionuclides and toxic chemicals used in the analysis exceed all actual process concentrations expected and are much higher than the nominal concentrations expected to be processed during the operational period; (3) concentrations of nuclides expected to be highly variable in the wastewater ( $\mathrm{Sr}$ 90, Tc-99, I-129, short-1ived gamma emitters, total alpha) are adjusted for this scenario to broaden the safety envelope to encompass compositions that may not be blended due to operational constraints in the Tank Farms (this change is why the EDE results in the Draft SAR are higher than in the Hazards Analysis); (4) the entire volume of salt solution in the SSHT is released from both primary and secondary containment and evaporates completely in 2 hours; (5) no credit is taken for operator 
intervention to minfmize or contain the spill; (6) no credit is taken for secondary contalnment provided by the concrete dike surrounding the SSHT; (7) no credft is taken for absorption of any salt solution into the ground outside the dike. (Ref. 10)

An extremely high energy event must occur to evaporate the assumed 45,000 gallons of salt solucion. To evaporate only the water in the salt solution would require a total sensible heat input of about $9,300,000$ Kilocalories $(37,000,000$ BTU). This sensible heat corresponds to the amount of heat generated from combustion of about 1.5 tons of cosl. Furthermore, all the heat must be absorbed by the salt solution with no heat losses to the surroundings just to vaporize the water. Except for water, tritiated water, and benzene, all chemlcal and radiochemical species are present as ionic species in the basic solution ( $\mathrm{pH}>10)$. Their Ionic nature reduces volatility significantly for these species in the wastewater.

No credible initlating event meets the high-energy requirements of the accident scenario, especially since the salt solution is chemically stable and noncombustible. Thus, this bounding scenario describes the results of an accident that is well beyond the design basis for the Z-Area facilities. Dose calculations from this bounding accident scenario are thus very conservative (high by at least two orders of magnitude), especially since obvious mitigating conditions are ignored in the analysis. (Ref. 10)

The consequences of this bounding unmitigated accident scenario shows that the maximum Individual whole body exposure calculated for an employee is an EDE of 1.97 Rem and the maximum organ dose (bone surface) is 16.2 Rem for this single hypothetical event. The maximum exposures for an offsite individual for the bounding unnitigated accident scenario for Z-Area are calculated to be an EDE (whole body) of 3.9 mRem ( $0.0039 \mathrm{Rem}$ ) and a maximum organ dose (bone surface) of $32 \mathrm{mRem}$ ( 0.032 Rem). (Ref. 10) These calculated doses from this accldent scenario are well within the upper limic established for a Low Hazard Nuclear Fac1lity. 2-Area operations pose no undue radfation hazard to the public or site employees, even when the release of the bounding accident scenario is considered. As noted above, the conservatism used in the bounding accident scenario clearly infers that any credible event in Z-Area would have a minor impact on doses to either onsite or offaite populations.

\subsection{DESGRIPTION OF FACILITIES IN Z-AREA}

Z-Area contains both the Saltstone Production Facility and the Saltstone Disposal Facility. The Saltstone Production Facllity combines "uixed waste" wastewater with a blend of cament, flyash and slag to generate nonhazardous hWW Saltstone grout. The Saltstone grout is then pumped through 3 -inch pipelines from the Saltstone Production Facility to a covered cell of an above-grade vault located in the Saltstone Disposal Facility. The grout solidifies into a monolithic, nonhazardous solid waste called Saltstone. No wastewater streams are released directly to the environment or sent to other facilities from 2-Area.

Saltstone production and LLW disposal operations began in Z-Area in 1990. Prior to construction of the facilities, permits were obtained from the U.S. Environmental Protection Agency (EPA) and the South Carolina Department of Health and Environmental Control (SCDHEC). The state of South Garolina is concerned with the protection of 
water resources within the state. The SCDHEC regulates waste treatment and disposal facilities to assure storage, treatment, and disposal will not degrade water quality.

Although the Nuclear Regulatory Commission has no regulatory authority over DOE sites, DOE uses the NRC regulations as a basis for their own regulatory DOE Orders and guidance letters. The method of disposal used for Saltstone is consistent with NRC requirements for Class C LLW waste disposal. However, in response to the ALARA principle specified in DOE Order $5820.2 \mathrm{~A}$ and to minimize the long-term environmental impact of Saltstone disposal, WSRC has established a goal to keep the overall average concentration of long-ifved radionuclides in all the Saltstone disposed in Z-Area vaults at or below NRC IImits for Class A LLW waste. (Ref. 14) This goal does not preclude the disposal of occasional batches of Saltstone that could contain some radionuclides at a concentration above the class A limits as defined by NRC, providing all performance objectives are acheived. The Saltscone Disposal Facility design and Z-Area operating permits do not permit disposal of Saltstone that contain any radionuclides that exceed class C limits or the disposal of any hazardous waste.

The Department of Energy approved radioactive Saltstone production and disposal operations in Z-Area based on conservative wastewater feed specifications that were proposed during the Startup Authorization Review conducted in 1990. These specifications are based on extensive laboratory testing and earlier modeling studies that served as the basis for the design and operations in Z-Area.

\subsection{SALTSTONE PRODUCTION FACILITY}

\subsubsection{Equipment}

The Saltstone Production Facility is permitted by the SCDHEC as a wastewater treatment plant. Major equipment components of the Saltstone Production Facility include: (1) bulk storage silos for dry feeds; (2) dry feed blending and transfer equifpment; (3) the Salt Solution Hold Tank (SSHT) that recelves wastewater to be processed; (4) the Flush Water Recelpt Tank (FWRT) that receives equipment flushes and liquids collected in sumps located in 2-Area; (5) a mixer that blends wastewater (and flush water, when necessary) with dry feeds to produce a nonhazardous Saltstone grout; (6) a Saltstone hold tank that provides a reservoir of grout to prevent cavitation of the grout pumps; (7) grout pumps; and (8) pipelines that are used to transfer wastewater solutions, flush water and Saltstone grout within the production faclilty and grout to the disposal vaults.

\subsubsection{Process}

The Saltstone production process is very simple. Dry feed materials are blended automatically in the desired ratio and transferred pneumatically to the Premix Feed Bin. Premix is then fed at a preset rate to a mixer. Wastewater is also fed to the mixer where it is mixed with the premix to produce saltstone grout. The grout is then pumped to the disposal vaults. Except for special design considerations and operating procedures because of the presence of low levels of radionuclides, the process is identical to a concrete batch plant.

\subsubsection{Radiological Design, Controls, and Permitting}


Shielding, containment, off-gas treatment, operational procedures, and administrative controls are in place to assure that employee exposure to radiological and chemical hazards are minimized in the Saltstone Production Facility. Although the wastewater sent to Z-Area is a mlxed waste ( 1 ; e., hazardous and radioactive) due to hlgh pH and the presence of radionuclides, the Saltstone Production Facility is totally unclosed and no liquid effluents are released directly to the environment.

Tanks and processing equipment with potentially hazardous materials in them are 1solated from the immediate environment by secondary containment. The SSHT and the FWRT are carbon steel tanks surrounded by a concrete dike. The dike is sized to assure that the entire contents of the tanks will be contained in the event of a catastrophic fallure of tanks. All other processing equipment is located in a process building constructed of reinforced concrete that contains a sump designed to collect any spilis.

Although hazardous (mixed) wastewater is processed in Z-Area, an exemption from requirements of the Resource Conservation and Recovery Act (RCRA) was granted by SCDHEC for the Saltstone Production Facility because it is totally enclosed and liquid effluents are not released directly to the environment. Totally enclosed facilities are specifically exempted by the RCRA. Thus the saltstone Production Facility functions as a wastewater treatment plant that converts mixed waste to Lun Saltstone grout that is suitable for disposal in the vaults of the Saltstone Disposal Facility as nonhazardous waste.

\subsection{SALTSTONE DISPOSAL FACILTTY}

Saltstone is classified as a nonhazardous Industrial waste as defined by SCDHEC regulations. The Saltstone D1sposal Facility is permited as an industrial solid waste disposal landfill site. SCDHEC perults require periodic reports to the state that describe LLW wastewater composition (chemical and radiochenical), physical and chemical test results on the Saltstone produced, and groundwater monitoring results.

Because Saltstone is nonhazardous, the Saltatone Disposal Facility is designed as a "controlied release" landfill disposal site. The only long-term potential risk to the environment and to the general public is through possible degradation of surface water or groundwater quality due to a release of chemical or radioactive pollutants from the disposal site Into surface streams or into the underlying groundwater. Such releases are aitigated by the surrounding concrete vaults and the Saltstone waste form, itself. Final site closure will further mitigate the potential risk to the environment.

\subsubsection{Layout and Capacity}

In the present disposal site layout, up to fifteen concrete vaults will be constructed for Saltstone disposal. Fourteen of these vaults will each have external dimensions of approximately $200 \mathrm{ft}$ wide by $600 \mathrm{ft}$ long by $25 \mathrm{ft}$ high. The other vault (Vault 1) $1 \mathrm{~s}$ approximately $100 \mathrm{ft}$ wide by $600 \mathrm{ft}$ long by $25 \mathrm{ft}$ high. Each of the fourteen larger vaults will be divided into twelve cells that are approximately $100 \mathrm{ft}$ wide by $100 \mathrm{ft}$ long by $25 \mathrm{ft}$ high. Vault 1 is divided into 6 celis with the same approximate cell dimensions as the larger vaults. 
About two-thirds of the Z-Axea disposal capacity will be used to dispose of mixed wastewater generated from existing HLW wastewater inventory now stored on the site in the F/H Tank Farm Facilities. Based on projected average compositions of wastewater that w11 be generated from HLW wastewatex and the ETF, the average concentration of radionuclides in Saltstone will be well below the Class A disposal limits defined by the Nuclear Regulatory Comission (NRC). (Ref. 14) South Carolina does not directly regulate radionucIlde disposal at the SRS, but the operating permits for $Z$-Area require perlodic reporting of the concentration of radionuclides in waste processed. Disposal of waste that exceeds IRC Class A criteria must also be reported to sCDHEC. Records must be maintained that reflect the totel inventory of radionuclides in the disposal vaults.

Z-Area must operate for about 12 years at full production capacity to dispose of the mixed wastewater from existing HLW wastewater inventory and the ILW wastewater generated by the ETF during this same operating perlod. This volume of saltstone will fill about elght large vaults plus the space in the smaller Vault 1 . The existing HWW wastewater inventory represents $30-35$ years of sas production. Assuming the future HLW waste generation rate is comparable to the historical rate, the remaining six vaults provide disposal capacity for at least 15 years additlonal production at the SRS. Active disposal operations in Z-Area are projected to continue for about 30 years before the permitted disposal capacity is reached.

\section{2 .2 Operaclons Prior to Closure}

The low concentration of game-emitting isotopes in Saltstone allows a delay of backfilling operations at the Saltstone Disposal Fac1lity. Minimal backfilling around the vaults prior to final closure operations is planned, principally to control surface water runoff and erosion. Thus the Saltstone Disposal Facility will consist of above-grade vaulta during the operational period. Procedures are in place that require perfodic inspection and radiological surveys of the vaults during the optrational pertod.

Delay of beckfilling allows the closure plan to be changed, if desired or necessary, to take advantage of improved closure technology or to meet changes in regulations that may occur during the projected 30 years of disposal operations. Final closure operations at the site will not begin unt1l most (or al1) of the vaults have been fllled wth Saltstone and capped with a layer of clean grout and a layer of concrete. Delaying final closure operations until near the end of active disposal operations also reduces the likelihood of having to do site remediation after closure. Because the final closure is delayed, the RPA prescribed by DOE Order 5820.2A 15 not pertinent to safety issues during the operational period covered by the SAR.

\section{2 .3 Site Closure}

A site closure plan was included as a part of the $Z$-Area construction permit application. The conceptual plan outlined in the permit application contained insufficient detail to assess tts acceptability for long-term environmental performance. A detailed closure plan has now been developed to serve as a basis for the radiological performance assessment. As presently conceived, the closure plan is designed to minimize water infiltration through the vaults and transport of potential contaminants from the vaults into underlying groundwater. (Ref. 15) 
WESTINGHOOSE 8AVANNAH RIVER COMPANY

Justification for continued Operation of the sRs saltstone Facilities (z-Area)
Report:

page:

(U) Date:
WSRC-RP-92-444

8 of 16

$3 / 31 / 92$

Key elements of the closure design include backfilling with native soil, placing a clay cap over the site to minimize infiltration to the vaults, and placing a gravel layer above the clay cap. The gravel layer will reduce the hydrostatic head and provide a capillary break above the clay cap to minimize infiltration through the cap. A geotextile fabric will be placed over the gravel layer to minimize infiltration of fine-particle soil into the gravel layer from additional native soil that wIIl be placed over the gravel layer. Shallow-rooted bamboo, a terminal vegetation recommended by the U. S. Soil Conservation Service, will be planted on the site to minimize encroachment by deep-rooted plants such as pine trees whose roots could penetrate the clay cap and thus increase infiltration through the waste. The low hazard nature of the vaults and the overall disposal site was established in hazards analyses (See Section 3.5).

\subsection{JUSTIFICATION FOR CONTINUED OPERATION}

In the ORR for Z-Area, conducted In 1988, DOE-HQ (EH) concurred with DOE-SR that all safety issues have been adequately addressed in existing safety documentation for $z$ Area: However, the documentation did not match the format prescribed in DOE Order $5481.1 \mathrm{~B}$, and thus did not fully comply with the Order. (Ref. 3, 4) In the subsequent Startup Authorization Review completed in 1990, this noncompliance issue was clearly identified as one of form, not substance, because Z-Area operations are Low Gazard (locallzed consequences only). The Startup Review Affidavit addressing this issue only requires WSRC to forward a copy of a Z-Area SAR in the proper format to DOE-HQ for inclusion in the files for Z-Area after it is issued; further DOE revlew of the SAR is not needed. (Ref. 5)

Work to complete the Z-Area SAR has not been funded in FY92, due to budgetary constraints and a need to divert proposed funds and resources to higher priorities within the 1780 project. Suspending operations of a Low Hazard Facility like Z-Area because funding is unavailable to issue safety docunentation in a specifled format is not reasonable, especially since DOE has already concurred that all safety issues have been addressed. The lack of a SAR for Z-Area does not alter the conclusion that the risk of continued operations in Z-Area is well below specified DOE and IRC criteria for a Low Hazard operation.

If 2-Area operations are suspended for longer than 90 days, another operational Readiness Review (ORR) and/or startup authorization review would also be required. For a low-hazard facility such as Z-Area, a restart review is neither cost-effective nor justifled. Furthermore, halting $z$-Area operations is not in the best interest of public safety, since storage of mixed waste or $\mathrm{HLW}$ in liquid form poses a much higher risk to site employees and the public.

\subsection{FACILITY EQUIPMENT GHAKGES}

Transition to a DOE defined Conflguration Management Program is well underway in $z$ Area. Commitment to baseline and configuration control will further reduce the likelihood of introducing an increased risk from changes that are not documented or analyzed in existing safety documentation. A documented system for Configuration Management is now in place for Z-Area and will ensure all operations are within the safety envelope defined by safety documentation. No safety class items have been identified for Z-Area equipment and operations. 


\begin{tabular}{|c|c|c|c|}
\hline WEGTINGHOUSE BAVAMIAR RIVER COKPANY & & Report: & WSRC-RP-92-444 \\
\hline $\begin{array}{l}\text { Justification for Continued operation } \\
\text { of the 8Rs galtstone racilities (z-nrea) }\end{array}$ & (U) & $\begin{array}{l}\text { page: } \\
\text { Date: }\end{array}$ & $\begin{array}{l}9 \text { of } 16 \\
3 / 32 / 92\end{array}$ \\
\hline
\end{tabular}

All changes to components, equipment, procedures, systems, or waste stream compositions are subjected to a safety review to determine if the changes involve an Unrevlewed Safety Question (USQ). Reviews and analyses are documented, and approprlate authorization Is obtained prior to implementing any proposed changes. Changes to equipment and control software axo verifled and functionally tested prior to actual use in the process. These changes In design are documented on as-bullt drawings. One condition of the operating permit for the Saltstone Production Facility also requires that any changes in the equipment configuration must be revlewed and approved by sCDHEC before the change can be implemented. Thus SCDHEC provides independent oversight for configuration control of hardware and equipment changes for $\mathbf{Z}$-Area operations.

Since Z-Area startup, three modifications to the equipment and process have been implemented: (1) the fire water system has been upgraded to Improve fire protection; (2) piplng has been modified to enable the use of either salt solution or fresh water to flush operating equipaent; and (3) a centrifugal pump on the the flushing system has been replaced with a positive displacement pump. The use of salt solution to flush reduces the amount of waste generated as a result of the treatment process in Z-Area, in accord with DOE directives to minimize waste generation. The positive displacement pump has improved reliability and control on the flushing system. These changes were subjected to independent review and approved by WSRC, DOE, and SCDLEC before they were implemented. The draft SAR reflects these changes as a part of the process description.

\subsection{SUPPORTIKG DOCUMBNTIIOA}

The Safety Assessment Document (Ref. 2) and subsequent hazards analysis (Ref. 7, 8, 9) define the current safety envelope for Z-Area operations. These analysis clearly shgw that Z-Area operations are Low Hazard, as defined by DOB. Because work was suspended on the Z-Area SAR at the beginning of FY92, an independent WSRC review has not been completed for the WSRC Review Draft that covers the safaty analysis of $\mathrm{z}$ Area operations. (Ref. 10) However, results contained in the Draft SAR clearly suppoit approved documentation that shows the Low Hazard nature of all $Z$-Area operations.

\subsection{DOSE CONVERSION FACTORS}

International Combsion on Radiological Protection-2 (ICRP-2) Dose Converaion Factors were used in the safety analysis summarized in the SAD for Z-Area. ICRP-30 Dose Conversion Factors were used in the Hazards Analysis and the safety analysis summarized in the Review Draft of the Z-Area SAR. The doses cited in the Summary and in section 3.5 (below) for the Hazards Analysis and the Draft SAR reflect ICRP-30 dose methodology. 


\subsection{POPULATION DATA BASE}

The most current population data base for 1989 was used to establish the EDE values for onsite and offsite populations in the Hazards Analysis and the Review Draft of the Z-Area SAR. (Ref. 7, 8, 10) The SAD uses the 1980 population data base. (Ref. 2)

\subsection{DOSE RECIPIENTS}

Based on dose and risk analysis in the SAD using ICRP-2 dose conversion factors, risk to the offsite population is $9 \mathrm{E}-6$ person-rem/year, risk to the onst te population is 2E-6 person-rem/year, and risk to the maximum off-site individual is $2 \mathrm{E}-9 \mathrm{rem} / \mathrm{yr}$. (Ref. 2) The Hazards Analysis, using source terms based on the feed specifications in the TA, show that the maximum individual EDE (ICRP-30 methodology) for an onsite employee and at the site boundary are well within the upper limit for a Low Hazard Facility. (Ref. 7, 8):

$\begin{array}{llc} & \begin{array}{c}\text { Kax. Indiv. } \\ \text { EDE at } \\ 100 \text { Yeters }\end{array} & \begin{array}{c}\text { Kax. Indiv. } \\ \text { EDE at } \\ \text { Site Boundary }\end{array} \\ \text { Vaults } & \begin{array}{l}0.644 \text { Rem } \\ \text { SSHT }\end{array} & 0.001 \text { Rem } \\ \text { Low Hazard LImIt } & 1.03 \text { Rem } & 0.002 \text { Rem } \\ & 5.00 \text { Rem } & 0.500 \text { Ren }\end{array}$

Although the review of the safety analysis in the WSRC Review Draft of the Z-Area SAR (Ref. 10) has not been completed to enable issise of the report, results in the Draft clearly show that Z-Area is a Low Hazard Facility. Radiological hazards during norial operations are based on stack releases from the Saltstone Disposal Facility. The wdrst unmitigated accident scenario was developed to bound all credible events that could be conceived for Z-Area operations. The assumptions used in this hypothetical bounding accident scenario exceed any design basis accident for Z-Area. An extremiely high energy event would have to occur to evaporate the assumed 45,000 gallons of released sait solution in two hours. Ho credible initiating event meets these requirements. Risk was not determined. because no realistic initiating event for the accident scenario could be formulated, Calculated EDE's in the draft SAR report are tabulated below. Results from the Draft SAR are higher than the results from the Hazards Analysis above because source terms were changed to encompass a broader range of species that will vary in the wastewater. (compared in Table 3.6 below).

\section{DORST DNATTIOATED ACCIDENT SCERARIO}

Max. Indiv. EDE at 100 Meters

Whole Body

Maximum Organ
$1.97 \mathrm{Rem}$

16.2 Rem
Max. Indiv. EDE at Site Boundary

3. 9E-3 Rem

3.2E-3 Rem 50-mile

offiste

Population

24 person-Rem

198 person-Rem 


\begin{tabular}{lll}
\hline WEBTIMGHOO8E 8AVANHAH RIVER COMPANY & Report: & WSRC-RP-92-444 \\
Jugtification for Continued Operation & page: & 11 of 16 \\
of the sRs saltstone Facilities (z-Area) & (U) Date: & $3 / 31 / 92$ \\
\hline
\end{tabular}

Results in the Draft SAR show that EDE's from normal operations are Insignicant: NORMAL OPERATIONS

$\begin{array}{llll}\begin{array}{c}\text { Max. IndIV. } \\ \text { EDE at } \\ 100 \text { Yoters }\end{array} & \begin{array}{c}\text { Max. Indiv. } \\ \text { EDE at } \\ \text { Site Boundery }\end{array} & \begin{array}{l}\text { 50-mile } \\ \text { Offsite } \\ \text { Population }\end{array} \\ \text { Whole Body } & 1.4 E-5 \text { Rem } & 3.6 E-9 \text { Rem } & 1.0 E-4 \text { person-Rem } \\ \text { Maximum Organ } & 4.1 E-5 \text { Rem } & 1.8 E-8 \text { Rem } & 4.1 E-4 \text { person-Rem }\end{array}$

\subsection{SOURCE TERKS}

Present operations in Z-Area are controlled under an approved Test Authorization (TA). (Ref. 11) A procedure that defines waste acceptance criteria for $z$-Area 1 s being drafted to replace the $T A$ as a basis for controlling waste stream compositions sent to Z-Area within the defined safety envelope. The limits in the TA, the proposed limits for the WAC (including ALARA guide linits), a description of process and quallty controls, and a summary of operating experience to date were recently presented to the Defense Nuclear Facility Safety Board. Charts used in this presentation are included with this JCO. (see Attachment 1)

Wastewater generators must provide evidence of compllance with TA IImits and criterla before wastewater can be transferred to Z-Area for processing. Any proposed changes to the process, equipment, or the source terms used to estabiish the safety envelope (or the waste acceptance criteria) for wastewater transferred to Z-Area will require review to establish if an Unrevlewed Safety Question (USQ) exists as a result of a proposed change. Limits defined by the SAD and Hazards Analysis will provide the safety standard for comparison in a USQ determination until the SAR is 1ssued. Addifflonal analysis, documentation and approval in accordance with WSRC-11Q, Section 3. Fo, will also be required prior to laplementing any change. Resolution of a USQ wilj become an addendum to existing safety documentation.

Any new components not specifically covered in current permits, limits or criterla must be tested for regulatory compliance prlor to introducing such components into the wastewater sent to Z-Area. Approval by SCDHEC must also be obtained before wastewater containing new components can be sent to Z-Area for treatment and disposal. The compositions of existing and projected waste streans are based on analyses of feeds to processes used by waste generators that send liquid wastewater to Z-Area. Feed LImits in the IA (Ref. 11) provide the current bases for Z-Area operations; TA limits are based on the SAD and supplemental Hazards Analysis (Ref. 2, $7,8,9)$. Actual compositions of waste streams processed to date are well within these limits. (see Table 3.6)

The assumed waste composition used in the bounding unnitigated accident scenario in the Draft SAR is extremely conservative and assumes that all radioactive specles that could be present are at their maximum value in the 45,000 gallons of waste that is released. The source term for total alpha has been Increased by about a factor of 3 above the source terw used in the Hazards Analysis. Alpha is conservatively assumed to be all Pu-238 for purposes of dose calculations in the Draft SAR and Hazards Analysis. The dose contribution of $\mathrm{Pu}-241$ is a part of the other beta-ganma used as 


\begin{tabular}{|c|c|c|c|}
\hline WESTIRGEOUBE SAVAXWAH RIVER COKPAKY & & Report: & WSRC-RP-92-444 \\
\hline $\begin{array}{l}\text { Justification for continued operation } \\
\text { of the sRs galtstone Bacilities (z-Area) }\end{array}$ & (U) & $\begin{array}{l}\text { page: } \\
\text { Date: }\end{array}$ & $\begin{array}{l}12 \text { of } 16 \\
3 / 31 / 92\end{array}$ \\
\hline
\end{tabular}

a source term In the Draft SAR. Isotopes of nickel are included as a consequence of the NRC Class A criteria, and are imposed as a part of the Z-Area operating permits, but they have minimal impact on the radiological risk. The nature of treatment processes (filtration) that produce wastewater sent to Z-Area preclude the presence of significant quantities of nickel in the waste. These upstream processes also eliminate criticality as a credible event In Z-Area because of low solubility. (Ref. 9) Source term concentrations are compared in Table 3.6.

TABLE 3.6

SPECIFIC RADIONUCLIDES IH WASTEWATER SEHE TO Z-AREA $(\mathrm{nCl} / \mathrm{g})$

\begin{tabular}{|c|c|c|c|c|}
\hline Ac & $\begin{array}{c}\text { TA } \\
\text { Icceptance } \\
\text { IImit } \\
\end{array}$ & $\begin{array}{l}\text { Assumed } \\
\text { Conc. } \\
\text { In SAR } \\
\end{array}$ & $\begin{array}{l}\text { Draft HAG } \\
\text { Acceptance } \\
\text { Linit } \\
\end{array}$ & $\begin{array}{l}\text { Kaximum } \\
\text { Since } \\
\text { Startup }\end{array}$ \\
\hline $\begin{array}{l}F-3 \\
C-14 \\
N 1-59\end{array}$ & $\begin{array}{r}1,800 \\
800 \\
23,000\end{array}$ & $\begin{array}{r}1,800 \\
800 \\
23,000\end{array}$ & $\begin{array}{r}1,800 \\
800 \\
23,000\end{array}$ & $\begin{array}{l}21 \\
0.39 \\
<0.0002\end{array}$ \\
\hline $\begin{array}{l}\text { N1-63 } \\
\text { Co-60 } \\
\text { Sr-89/90 }\end{array}$ & $\begin{array}{r}3,700 \\
7 \\
40\end{array}$ & $\begin{array}{r}3,700 \\
70 \\
120\end{array}$ & $\begin{array}{r}3,700 \\
7 \\
40\end{array}$ & $\begin{array}{l}0.0008 \\
0.06 \\
0.11\end{array}$ \\
\hline $\begin{array}{l}\text { Tc-99 } \\
\text { Ru-106 } \\
\text { Sb-125 }\end{array}$ & $\begin{array}{r}320 \\
120 \\
75\end{array}$ & $\begin{array}{r}1,000 \\
600 \\
150\end{array}$ & $\begin{array}{r}320 \\
460 \\
.75\end{array}$ & $\begin{array}{l}45 \\
0.60 \\
0.40\end{array}$ \\
\hline $\begin{array}{l}I-129 \\
\text { Cs }-137 \\
\text { Eu-154 }\end{array}$ & $\begin{array}{r}2 \\
1000 \\
16\end{array}$ & $\begin{array}{r}20 \\
100 \\
16\end{array}$ & $\begin{array}{r}2 \\
100 \\
16\end{array}$ & $\begin{array}{l}0.0044 \\
1.4 \\
0.30\end{array}$ \\
\hline $\begin{array}{l}\text { Pu-241̀ } \\
\text { Other B\% } \\
\text { Total Alph }\end{array}$ & $\begin{array}{c}600 \\
- \\
18\end{array}$ & $\begin{array}{r}-- \\
4,000 \\
50\end{array}$ & $\begin{array}{l}600 \\
-- \\
18\end{array}$ & $\begin{array}{c}0.003 \\
0.1\end{array}$ \\
\hline
\end{tabular}

\subsection{CHEMICAL haZARDS}

As noted in the SAD (ref. 2) and the Draft SAR (Ref. 10), the wastewater sent to $z$ Area contains hazardous substances. However, concentrations of these contaminants are low and do not present any exposure hazard to workers. Sodium hydroxide, the one hazardous constituent that is present at a higher concentration, can be safely handled in accordance with standard Industrlal practices. Z-Area operations pose no significant chemical hazards to either onsite or offsite populations. (ref. 2,10 )

\subsection{LEVEL OF DETAIL}

During the ORR and Startup Authorization Review for Z-Area, DOE concurred that existing safety documentation for Z-Area adequately defines an envelope of safe operation. All studies to date show that 2-Area operations are clearly Low Hazard. Lack of safety documentation written to the level of detall and in the precise format 
spectfled in DOE Orders does not alter the conclusion that continued operations in $Z$ Area will not pose any undue risk to employees or to the general public. WSRC will 1ssue a Z-Area SAR, when funding to complete the work is provided. Administrative and procedural controls already in place, the Implementation of the Unreviewed Safety Question Determination procedure for proposed changes, the Configuration Management Program, and the Technical Review system provide the necessary oversight to ensure operations in 2-Area are maintained within the safety envelope defined by safety documentation. Until the SAR is issued, the SAD and the supplemental Hazards Analyses serve as the basis for USQ determinations. (Ref. 2, 7, 8, 9)

\subsection{RISK ANALYSIS}

The dose consequences of the hypothetical unmitigated accident scenario used in the Draft SAR are well within the bounds established by Federal Regulations, DOE Orders, NRC regulations or industry standards. The frequency of natural phenomena and internal Initiating events were determined for Z-Area to establish if the frequency of any high energy event was credible that could provide the necessary conditions to vaporfze 45,000 gallons in two hours. None could be identified that would not require collusion or sabotage, conditions that are considered as a part of security, not safety. Because no credible initiating event for this scenarlo could be postulated, separate risk analysis for the Low hazard Z-Area operations was deemed unnecessary. All low energy initiating events are bounded by the unmitigated accident scenarlo. (Ref. 10)

\subsection{SAFE SHUTDOWN}

In the context of this report, safe shutdown and/or condition implies that no events can occur that will cause undue risk to the health and safety of the public. Safe shutdown activities would include those required to preclude or mitigate the consequences of those events to a level not exceeding off-site exposure limits for abhormal or accident conditions. For Z-Area, the hazards posed to the general public are so low, that a bounding accident scenario does not even exceed the limits specified for normal operations at a DOE site. However, systems and procedures are in place that place the facilities in a safe shutdown status in the event of an emergency.

\subsection{RARYER PLOTS}

The radiological and chemical hazards for Z-Area operations are deemed too low to justify the time and expense of separate risk analysis, as noted in section 3.8. Accordingly, corresponding Farmer Plots were not prepared.

\subsection{SARETY RELATED SYSTEMS}

No safety class items have been identifiad that are required to mitigate the consequences of any credible event related to normal operations, abnormal operations, or accidents in Z-Area. The bounding accldent scenario that has been analyzed exceeds any credible design basis accident that can be visualized. Even under the conditions assumed for the bounding accident scenarlo, risks are well within the linits for a Low Hazard facility designation, as defined by $D O E$. 


\begin{tabular}{|c|c|c|}
\hline WESTIMGHOUBE BAVAMRAH RIVER COXPAMY & Report: & WSRC-RP-92-444 \\
\hline $\begin{array}{l}\text { Justification for continuod operation } \\
\text { or the sRs 8altstone racilities (z-Area) }\end{array}$ & $\begin{array}{l}\text { page: } \\
\text { (U) Date: }\end{array}$ & $\begin{array}{l}14 \text { of } 16 \\
3 / 31 / 92\end{array}$ \\
\hline
\end{tabular}

\subsection{EOUTEYERT UPGRADES}

Z-Area is a new facility. Upgrades to equipment are thoroughly reviewed and changes are implemented through the Configuration Kanagement Program, in accordance with the requirements of WSRC-11Q, Section 3.10 .

\subsection{COMPLIANCE HITH DOE ORDERS}

A compliance assessment against DOE Orders has been completed for $\mathrm{Z}$-Area as a part of the WSRC compliance self-assessment. A SAR In the prescribed format must be issued to comply with DOE Order 5480.1B and 5820.2A. A separate Radiological Performance Assessment (RPA) that projects the long-term enviromental acceptability of the Saltstone Disposal Facilicy must also be completed to fully comply with DOE Order 5820.2A. The SAR and the RPA are two separate reports that address different issues and concerns related to waste management practices. A SAR establishes the lamediate risk to life and health as a result of continuing operations.. A RPA provides a projection of the long-term environmental acceptability after a disposal site is closed; RPA results do not impact operational safety in Z-Area.

Analyses in the SAR provide reasonable assurance that Saltstone production and disposal can be accomplished without undue safety and health risk to onsite and offsite populations during the operational period. Analyses In the RPA assess the proposed closure plan to provide reasonable assurance that the presence of the waste in Z-Area will have minimal long-term impact on the environment. If the present closure plan proves to be deficlent, as determined by results in the RPA, then alternative closure plans will be tested to establish a plan that achieves the performance goals in DOE Order 5820.2A. Final closure is projected to be completed In approximately 30 years. The environmental risk of continued disposal operations in $z$ Area until the RPA is complated is minimal.

Work Eo complete a SAR and RPA Z-Area was begun in FY90 according to an approved complignce schedule. FY92 Funding to complete the SAR has been suspended by DOE, due to budgetary constraints, thus preventing completion in compliance with the approved schedule. Work to complete a Performance Assessment Report is funded for FY92.

The RPA is being prepared under separate funding on an approved schedule and is not an issue for continued safe operation of Saltstone production and disposal facilitles. The RPA addresses long-term environmental and regulatory issues that must be met after the site Is closed. The RPA should provide reasonable assurance that the overall disposal system and closure plan will meet the desired regulatory requirements for waste disposal. Operational safety is not an issue in the RPA.

\subsection{EXPIRATION DATE}

This JCO wil expire when an approved SAR In the proper forwat is issued.

\subsection{REFERMGGS}

1. Memo from C.W. Terre11, Acting Director, High Level Waste Division, DOE-SR, to D.B. Amerine, Manager, WSRC (DWPF), dated November 20, 1991, "Z-Area Safety Analysis Report." 
2. D.C. Aabye and D.H. Walker, DPSTSAD-200-4, "Safety Assessment - 200 Area, Savannah River Plant, SALTSTONE FACILITY," Science Applications International Corporation, December 1986.

3. Memo from James P. Knight, EH-33, to T.B. Hindman, DF-12, dated November 9, 1988, "Defense Waste Processing Facflity, Saltstone Facility Startup."

4. Memo from T.B. Hindman, DP-12, to James P. Knight, EH-33, dated November 21, 1988, "Defense Waste Processing Facility (DWPF) Saltstone Facility Startup."

5. Readiness Review Affidavits G-3 and S-6 in Attachment I of -Startup Readiness Revlew, Report of Findings, Saltstone Manufacturing and Disposal Facility," March 1990.

6. A. Lee Watkins, "Saltstone (Z-Area) Safety Analysis Report (SAR) (REF: ITR Mellen to distribution dated 11/1/90)." DOE Savamah River Operations Office, High Level Waste Division, Aiken, SC, March 29, 1990.

7. K. W. Stephens, "hazards Analysis for Saltstone," Interoffice Memorandum SRL. FPW-90-0195, Westinghouse Savannah River Company, Alken, SC, October 3, 1990.

8. K. W. Stephens, "Revised Hazards Analysis for Saltstone," Interoffice Memorandum SRL-FPW-90-0217, Westinghouse Savannah River Company, A1ken, SC, November 21, 1990.

9. M. S. Williams, "Saltstone Facilicy HAD Analysis - Criticality Calculations," Interoffice Memorandum SRL-THA-92-0073, WestInghouse Savannah River Company, March 18, 1992.

10. "Chapter 9 - Analysis of Operations" of the Review Draft of "Safety Analysis - Z-Aree Savannah River Site Saltstone Facility," July 1991. (WSRC review process suspended - not funded in FY92).

11. T. P. Gaughan, Test Authorization, "Transfer of Salt Solution fron Tank 50H to Saltstone," WSRC-0X-89-15-001 (Rev. 3), January 13, 1992.

12. Steven M. Blush, DOE (NS), "Recomendation of Office of Nuclear Safety-Startup of Saltstone Facillty, " May 25, 1990.

13. Leo P. Duffy, DOE, "Authorization for the Startup of the Saltstone Facility", June 1, 1990.

14. S. R. Wright, DOE, to J. B. Ruiter, SCDHEC, "Proposed Minor Changes to Z-Area Wastewater Treatment Facility, Construction Permit \#12,683". February 26, 1988,

15. C.A. Langton and D,G. Thompson, Conceptual Z-Area Cap and Second Generation Vault Design (u)," USRC-RP-90-992, Westinghouse Savannah River Company, Savannah River Laboratory, Alken, SC (October 12, 1990). 
ME8TIMGHOU8E BAVAMNAR RIVER COMPANY

Justification for continued operation of the sRs saltatone Facilities (z-Area)
Report:

page:

(U) Date:

WSRC-RP-92-444

\subsection{REVIEV AND APPROVAL BIGNATURES}

Prepared by:

J. R. Fowlex

Fellow Sclentist, WMEER/DWFF Technical

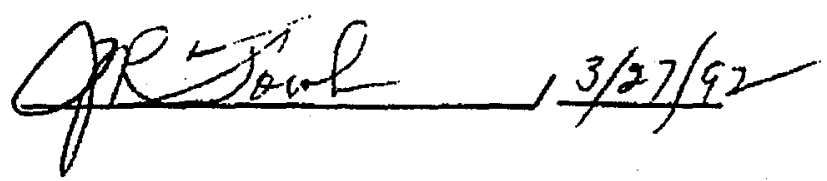

Approval signatures:

W. T. Goldston

Managex, WMER/DWPF Technical

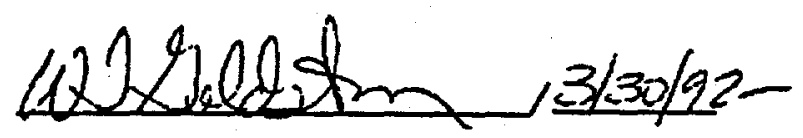

J. F. Ortaldo

Manager, WM\&ER/DWPF Technical

D. B. Amerine

Mansger, WMEER/DWPF Operations

D. W. Call

Manager, ESHSQA/Safety Department

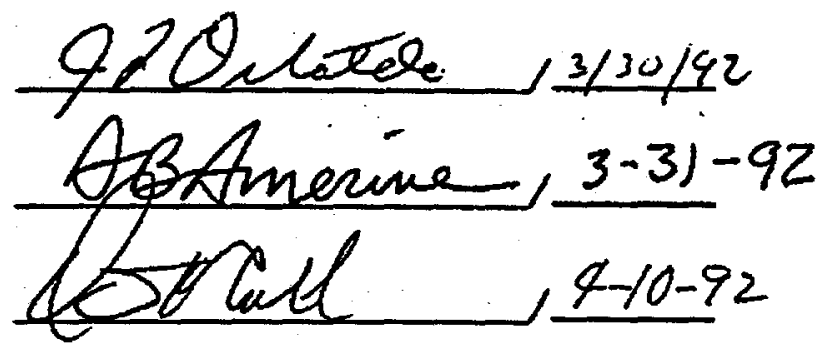

i 


\section{ATTACHARNT I FOR}

WSRC-RP-92-444

\section{CHARTS USED IN THE WSRC REVIEW FOR THE DNFSB}




\section{- SALTSTONE -}

SAMPLING AND TESTING TO CONTROL PRODUCT QUALITY AND THE Z-AREA PROCESS

\section{GOALS:}

- environmentally safe disposal of soluble waste solids

- DISPOSAl MEets OR EXCEeds REgULATORY NeEdS

- minimize radiation exposure of operating personNel.

- NEVER VIOLATE PERMIT

$\vdots$ 


\section{HIGHLIGHTS - SALTSTONE CONTROLS}

- Regulatory

- PRODUCT AND PROCESS CONTROL

- LUMITS v8. NOMINAL COMPOSITIONS

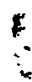

J. R. Fowlor $2 / 92$ 


\section{REGULATORY ANALYSES}

- REQUIREd by SCDHEC PERMIT

- Permanent record of results maintained

- Results open to SCDHEC

- DONE BY CERTIFIED LABS (off-sito)

- TCLP testing of Saltstone Sample (monthly)

- Chemical analyses of salt solution (quarterly)

- Radlochemical analyses of salt solution (seminannually)

- legal CONFIRMATION, BUt Unsuttable for control

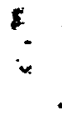

- basis for aNALYSES OF VARIOUS PROCESS SAMPLES

J. R. Fowler 292 


\section{EP-TOXICITY/TCLP TESTING OF SALTSTONE}

- certifies waste as non-hazardous

- RCRA does not apply

- Saltstone samples prepared dally

- One dally sample tested off-site each month

- If test sample fails tClp test, permit is Violated

- Production stopped, SCDHEC notified

- Additional samples tested to establish extent of violation

- if test sample passes tClp, production continues

- TCLP AND EP-TOXICITY RESULTS DEFINE LIMITS FOR HAZARDOUS COMPONENTS IN WAC

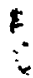




\section{PRODUCT AND PROCESS CONTROL}

\section{SIBATEGY:}

Acceptance criteria, feed speciflcations, process guldes are set and monitored to keep Saltstone well within applicable limits to meet or exceed standards.

- acceptance CRIteria based on most restaictive of Regulatory, PRODUCT, OR PROCESS LIMIT.

- ACCOMPLISHED bY SAMPLING AND ANALYSES BY GENERATORS AND Z-AREA

- assures disposal goals are met without undue analytical delays

$\vdots$

J. R. Fowier 292 


\section{ANALYSES AND REASONS}

- chemical for permit

- TCLP:

As, $\mathrm{Ba}, \mathrm{Cr}, \mathrm{Pb}, \mathrm{Se}, \mathrm{Ag}$, benzene, phenol

- Groundwater: $\mathrm{Cd}, \mathrm{Ha}, \mathrm{F}$

- RADIOChEMICAL

- Groundwater: Se-79, Sn-126, 1-129, Np-237

- NRC Class A: C-14, N1-59, NI-63, Sr-90, Nb-84, TC-99, Pu-241, alpha

- Rad. Prot:: H-3, Co-60, Ru-106, Sb-125, Cs-137, Eu-154

- CHEMICAL, PHYSICAL FOR PROCESS CONTROL

- anions: nitrate, nitrite, hydroxide, sulfate, chlorlde, carbonate

- metals: $\mathrm{Al}, \mathrm{B}, \mathrm{Na}, \mathrm{Mo}, \mathrm{K}, \mathrm{SI}$

- other: total org. C, alcohols, density, $\mathrm{pH}$, total solids, suspended solids

5

$*$ 


\section{WASTE ACCEPTANCE CRITERIA FOR Z-AREA}

- ReQUiRed per doe order 5820.2A for lLW disposal site

- WAC DRAFt nOW UNDER WSRC INTERNal ReView

- Z-AREA ACCEPTANCE liMITS BASED ON MOST RESTRICTIVE OF:

- Safety envelope limits from'SAD and Hazards Analysis

- Process knowledge

- Groundwater IImits

- TCLP results

- Radiation protection

- NRC waste classification

- Tank 50H Process Hazards Review

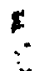

J. R. Fowler 292 
"DRAFT" WASTE ACCEPTANCE CRITERIA FOR Z-AREA

A. Hazardous Species $(\mathrm{mg} / \mathrm{L})$

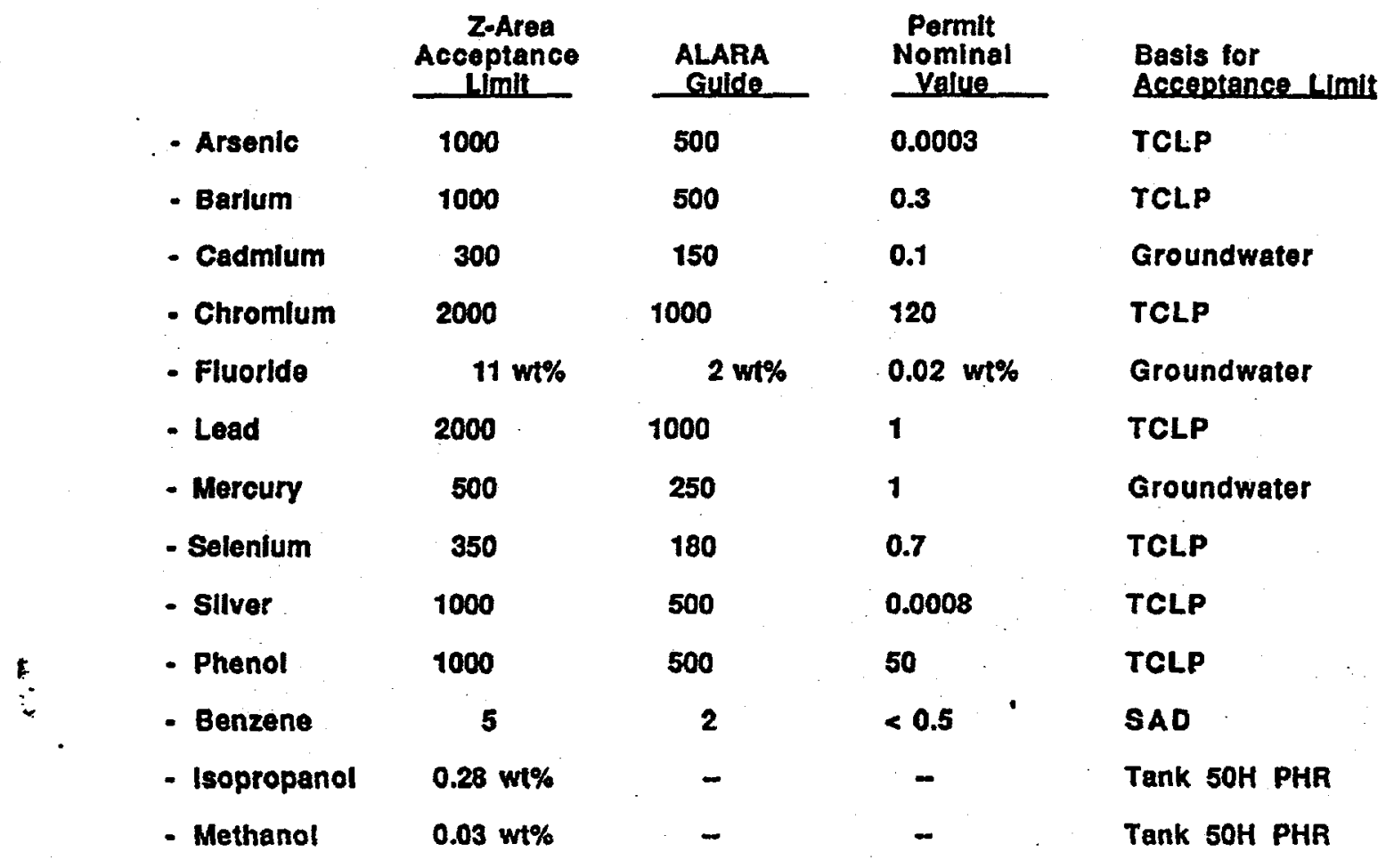

J. R. Fowier 292 


\section{B. Anionic Species}

\begin{tabular}{|c|c|c|c|c|}
\hline & $\begin{array}{c}\text { Z-Area } \\
\text { Acceptance } \\
\text { Limit } \\
\end{array}$ & $\begin{array}{l}\text { ALARA } \\
\text { Gulde }\end{array}$ & $\begin{array}{c}\text { Permit } \\
\text { Nominal } \\
\text { Yalue } \\
\end{array}$ & $\begin{array}{l}\text { Basis for } \\
\text { Acceptance Limli }\end{array}$ \\
\hline - Nitrate & $5.5 M$ & $4.5 \mathrm{M}$ & $2.1 \mathrm{M}$ & Process Knowledge \\
\hline - Free Hydroxide & $3.0 \mathrm{M}$ & $2.0 \mathrm{M}$ & $1.3 \mathrm{M}$ & Process Knowledge \\
\hline - Nitrito & $2.0 \mathrm{M}$ & $1.0 \mathrm{M}$ & $0.6 \mathrm{M}$ & Process Knowledge \\
\hline - Aluminate & $0.6 \mathrm{M}$ & $0.5 \mathrm{M}$ & $0.4 M$ & Process Knowledge \\
\hline - Carbonate & $0.4 \mathrm{M}$ & $0.3 \mathrm{M}$ & $0.2 \mathrm{M}$ & Process Knowledge \\
\hline - Sulfate & $0.3 M$ & $0.2 M$ & $0.1 M$ & Process Knowledge \\
\hline
\end{tabular}

$\because$

J. R. Fowler $2 / 92$ 


\section{General Radiological Properties and Alpha Emitters (nCi/g)}

\begin{tabular}{|c|c|c|c|c|}
\hline & $\begin{array}{l}\text { Acceptance } \\
\text { Limit }\end{array}$ & $\begin{array}{l}\text { ALARA } \\
\text { Guide }\end{array}$ & $\begin{array}{c}\text { Permit } \\
\text { Nominat } \\
\text { Yalue } \\
\end{array}$ & $\begin{array}{l}\text { Basis for } \\
\text { Acceptance Uimit }\end{array}$ \\
\hline - Gamma Control & 3 & $<1$ & $<0.4$ & Personnel Exposure \\
\hline - Total Alpha & 18 & 10 & 0.05 & Haz. Anal., NRC Class A \\
\hline - Np-237 & 0.03 & 0.01 & 0.0001 & Groundwater \\
\hline - Pu-241 & 600 & 200 & 0.01 & NRC Class A \\
\hline
\end{tabular}

NOTE: Total Alpha includos Pu-238, Pu-239, U-235, U-238, Cm-244. 


\section{Specific Radionuclides (nCi/g)}

- $\mathrm{H}-3$

- C.14

- N1-59

- NI-63

- Co-60

- Se-79

- St-90

- Nb-94

- Tc.89

- Ru-106

- Sb-125

- $5 n-126$

- $1-129$

- Cs-137

- Eu-154
Acceptance Limit:

1,800

800

23,000

3,700

7

12

40

20

320

46.0

75

250

2

100

15
ALARA Nominal Basis for Guide Value

200

200

5,000

1,000

1

3

20

5

200

60

20

20

120

1

45

1
30

0.004

0.0001

0.008

0.09

0.1

0.2

0.0004

30

15

4

0.08

0.02

20. 0.02
Acceptance Limit

Rad. Protection, Haz. Anal. NRC Class A

NRC Class A

NRC Class A

Rad. Protection, Haz. Anal.

Groundwater

Haz. Anal.

NRC Class A

Haz. Anal.

Rad. Protection, Haz. Anal.

Rad. Protection, Haz. Anal.

Groundwater

Groundwater

Rad. Protection

Rad. Protection, Haz. Anal.

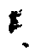




\section{SAMPLING TO MEET SOLUTION AND SALTSTONE SPECIFICATIONS}

- THREE SOLUTION CHECKS IN ETF

- All Inlets to ETF

- Every fourth concentrate batch from ETF evaporator to Tank 50H

- Monthly sample of Z-Area Feed Tank contents (Tank 50H)

- FIVE SOLUTION CHECKS IN ITP

- Every batch of dissolved salt solution sent to ITP

- Every precipltate slurry batch before flitration

- Every flltrate hold tank batch

- Flitrate Composite sample

- Monthly sample of Z-Area Foed Tank contents (Tank 50H)

- CHECKS IN Z-AREA

- Dally sample of salt solution (process control)

- Weakly solution composite sample (process history)

- Saltstone grout samples for process control, product control, certification

- Salt solution samples for permit requirements 


\section{CONCLUSIONS}

- MUltiple aNALYTICAL CHECKS bY GENERATORS, Z-AREA ASSURE:

- Environmentally safe disposal of soluble waste solids

- Saltstone meets are exceeds regulatory requirements

- Minimal radiation hazards to operalling personnal

- Never violate permit

- System in place to CONTROL saltstone pRoduct AND PROCESS

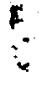

J. A. Fowler 292 
Distribution for WSRC-RP-92-444, "Justification for continued operation (JCO) of the SRS Saltstone Facility (z-Area) (u)", dated March 31, 1992.

\section{mSRe:}

N. C. Boyter, WM\&ER, 703-A

D. B. Amerine, DWPFO, 704-S

R. M. Satterfield, 703-A

J. F. Ortaldo, DWPFT, 704-S

W. T. Goldston, DWPFT, 704-S

J. R. Fowler, DWPFT, 704-Z

H. Bull III, DWPFT, 704-Z

D. G. Thompson, DWPFO, 704-Z

R. R. Campbell, ESH\&QA, 703-A

D. W. Call, ESH\&QA, 992-2W

N. F. Sadri, ESH\&QA, 992-2W

K. W. Stevens, SRTC, 992-1W

M. S. Williams, SRTC, 992-1W

D. H. Howard, SRTC, 992-1W

Records (4), 703-A

\section{DOE-gavannah River:}

I. Sjostrum, 703-A

C. W. Terrell, DWPD, 704-S

s. ordway, DWPD, 704-S

P. A. Polk, DWPD, 704-S

$\therefore$ 